\title{
Notes on the concept of Traditional Knowledge and its relation to Intellectual Property Rights ${ }^{1}$
}

\section{João Vitor de Freitas Moreira}

Filiação: Mestrando em Direito pela Universidade Federal de Minas Gerais

Orcid: https://orcid.org/0000-0002-8508-7699

Lattes: http://lattes.cnpq.br/2600550784355325

Google Acadêmico: https://scholar.google.com.br/citations?user=wLwKPj0AAAAJ\&hl=pt-BR

\author{
RECEBIBO 29/01/2019 \\ APROVADO 30/01/2019 \\ PUBLICADO 04/01/2019 \\ Editor Responsável: Carla Caldas \\ Método de Avaliação: Double Blind Review \\ E-ISSN: 2316-8080 \\ DOI: 10.16928
}

Abstract

The present work aims to explore some controversial issues that arise from the relationship between Traditional Knowledge and Intellectual Property Rights. I intend to use legal anthropology strategies to achieve a substantial critique of the patent rights and highlight the importance of Traditional Knowledge. Therefore, it is necessary to consider the semantic frontier the concept of Traditional Knowledge has established in the international scenario and present the tensions that it proposes to the boundaries of patent rights. Taking into account a conflict between epistemological sources, we offer offer a critical approach of the patent rights and how the applications based on Traditional Knowledge are improper.

keywords: Traditional Knowledge. patent. cosmology. perspectives. frontier.

\section{Notas sobre o Conhecimento Tradicional e sua relação com a Propriedade Intelectual}

\begin{abstract}
Resumo
O presente trabalho tem como objetivo explorar algumas questões controversas decorrentes da relação entre o conhecimento tradicional e a propriedade intelectual, nomeadamente os direitos de patente. Para tanto, utilizaremos as estratégias da antropologia jurídica para obter uma crítica substancial e destacar a importância do conhecimento tradicional como limite epistemológico e normativo. Portanto, é necessário considerar a fronteira semântica que o conceito de Conhecimento Tradicional estabelece no cenário internacional e as tensões que ele propõe aos
\end{abstract}

\footnotetext{
${ }^{1}$ This essay have financial support by Coordenação de Aperfeiçoamento de Pessoal de Nível Superior - CAPES.
} 
limites de uma patente. Levando em conta um conflito entre fontes epistemológicas, podemos apresentar uma abordagem crítica dos direitos de patente e como as aplicações baseadas no conhecimento tradicional são impróprias.

Palavras-chave: Conhecimento tradicional. patente. cosmologia. perspectivas. fronteiras.

\section{Notas sobre el Conocimiento Tradicional y su relación con la Propiedad Intelectual}

Resumen

El presente trabajo tiene como objetivo explorar algunas cuestiones controvertidas derivadas de la relación entre el Conocimiento Tradicional y la Propiedad Intelectual, en particular los derechos de patente. Para ello, utilizaremos las estrategias de la antropología jurídica para obtener una crítica sustancial y destacar la importancia del Conocimiento Tradicional como límite epistemológico y normativo. Por lo tanto, es necesario considerar la frontera semántica que el concepto de Conocimiento Tradicional establece en el escenario internacional y las tensiones que él propone a los límites de una patente. Teniendo en cuenta un conflicto entre fuentes epistemológicas, podemos presentar un enfoque crítico de los derechos de patente y cómo las aplicaciones basadas en el Conocimiento Tradicional son inapropiadas.

Palabras clave: Conocimiento tradicional. patente. cosmología. perspectivas. fronteras.

\section{Introduction}

There are many regimes of knowledge and culture that our vain metropolitan imagination supposes (CARNEIRO DA CUNHA, 2009, p. 239 , translated by the author) 
Notes on the concept of Traditional Knowledge and its relation to Intellectual Property Rights E-ISSN: 2316-8080

The TRIPS agreement ${ }^{2}$, signed in 1994, is commonly seen as the concretization of some proposals presented by the international community since the 1960 s, especially after the creation of World Intellectual Property Organization. The main objectives were (I) to promote the protection of intellectual property at a global level and (II) to harmonize the intellectual property laws worldwide (YU, 2009).

With an approach that pointed out to a maximization of Intellectual Property associated with economic growth, an Intellectual Property Rights perspective was predominant in the international scenario during that period. This perspective satisfied the classic metric of economic liberalism - one-size-fits-all (SILVA, 2013) - and performed a false symmetric view (CAROLAN, 2008) over the production of knowledge that lied behind the Intellectual Property discourse.

It does not require much effort to realize that the national contexts would diverge, once this symmetric view disregards the different levels of "development" or, to word it better, the different approaches of States regarding the market and Intellectual Property. Those ideas were finally questioned by the proposal that Brazil and Argentina presented at WIPO in 2004.

The proposal aimed to achieve a suitability of Intellectual Property Rights to the different contexts and realities. The referred proposal converged at the 45 recommendations ${ }^{3}$ of the WIPO Development Agenda (NATANEL, 2009), which were adopted in 2007 by the General Assembly. After this shift in the objectives of WIPO, many subjects were at discussion. One particularly important is de recommendation 18th of the Development Agenda, that is:

To urge the IGC to accelerate the process on the protection of genetic resources, Traditional Knowledge and folklore, without prejudice to any outcome, including the possible development of an international instrument or instruments (WIPO, 2007).

This recommendation sets the discussion I would like to debate: the Traditional Knowledge working as frontiers or point of tension to patent rights. To that end, I will make use of legal anthropology to present a robust approach of the concept, upon which the

\footnotetext{
${ }^{2}$ See WORLD INTELLECTUAL PROPERTY ORGANIZATION. Agreement on Trade-Related Aspects of Intellectual Property Rights (TRIPS). Available at: https://www.wipo.int/treaties/en/text.jsp?file_id=305907. Accessed on: 10 dez. 2018.

${ }^{3}$ WORLD INTELLECTUAL PROPERTY ORGANIZATION. The 45 Adopted Recommendations under the WIPO Development Agenda. [online] Available at: https://www.wipo.int/export/sites/www/ipdevelopment/en/agenda/recommendations.pdf. Accessed on: 10 dez. 2018.
} 
cosmological distinction between the Western knowledge and Traditional Knowledge arise. To interpret the current legal status in question, I will make use of the Clifford Geertz (1983) idea of “differente sense of law” and Eduardo Viveiros de Castro’s (2002) perspectivism.

Based on that, I intend to get into the discussion of art. 27 of TRIPS and try to answer the following questions: What makes an invention based on Traditional Knowledge patentable? What is the core that allows us to say about a distinctiveness that serves not only the legal requirements set forth in art. 27 but also constitutes an invention?

Despite that, to be fair with a research tradition, the words that follows do not have the intention to become true in a scientific sense, for we do not structure it into a theoretical perspective. Therefore, I prefer to take this text as an essay, incapable by nature to enter the hypothetic-inductive field. I try to reflect upon some important impasses such as: protection of Traditional Knowledge vs. innovation, bioprospection vs. biopiracy, development $v s$. conservation, just to name some of them.

Without further ado, in the first part I will discuss the traditional form in the legal field and the importance of the concept of Traditional Knowledge in national and international context, trying to present a more robust approach based on anthropology. In the second and final part I want to suggest that we need to go further in the analytical field and that the old legal forms do not help to verify the accomplishment of the recommendation 18 of WIPO Development Agenda.

\section{The Traditional Knowledge in focus}

After my unpretentious readings of Society against the State by Pierre Clastres, and my contact with a more sophisticated analysis by Eduardo Viveiros de Castro and Marilyn Strathern, I developed a deep interest on the different cosmogonies and cosmologies in the world, especially different perspectives and concepts that people ascribe to the world in order to explain the divergent singularities. At the beginning, it was nothing more than just a theoretical interest; however, today I realize the power of Anthropology and its discerned relation to Law.

That importance relies on the fact that any sort of normative concept should not be taken as universal and capable of (re)organizing and defining what is possible and what is not. Thanks to some major work in Legal Anthropology such as the one of Clifford Geertz, we now know that our way of expressing and solving conflicts is just a very restricted sensibility. To 
Notes on the concept of Traditional Knowledge and its relation to Intellectual Property Rights E-ISSN: $2316-8080$

interpret the current legal status, I take as an axiom that "law', here, there, or anywhere, is part of a distinctive manner of imagining the real" (GEERTZ, 1983, p. 184), which provides me with an essential tool to question the real meaning of intellectual property rights and put in the horizon what Geertz (1983) calls "different sense of law".

It is rather clear that to begin this discussion in the legal field is to put in question some solid barriers that constitute two different sides: one is the "real world" of the facts, and the other is the normative and sheer field of law. This view - that could be characterized as an “invented" ideology following Roy Wagner (1981) - does not provide us the ability to escape the frontier of the two sides that eventually conflict with one another. In fact, this ideology hides some of the complexity of the real world that do not operates at the level of norms and proportionate a sort of "decomplicated justice" (GEERTZ, 1983). The case of Traditional Knowledge is one proper example of this frontier that achieved an outstanding light in the field of Intellectual Property Rights, because its way of expression, as we shall see, does not fit into current legal definitions of patent, property, invention etc.

But it is not only because of this oppositions that the concept of Traditional Knowledge arrived at the legal field. It is necessary to go further and comprehend some interactions that I think can be exemplified by one of the first expeditions during the colonization of Spanish America, in sixteenth century. This expedition made by Francisco de Orellana went down to the Amazon river and something very interesting was described in the reports: "It is these Tapajozes people of self-respect, often feared by the surrounding nations, because they use such poison in their arrows that only with the one to make blood, they take the life without remedy" (CARVAJAL; ROJAS; ACUÑA, 1941). One could think that this little story does not have any sort of importance. But taking it as just a factual example, an important product was "invented" and revolutionized modern medicine.

At another place we have analyzed it (AUTOR, DATA) and remarked that although the reports were representing the sixteenth century, much can be said about the substance referenced as a "poison". Especially due to the scientific effort to discover the "right" composition of that poison, affecting research interests in the late nineteenth century and the beginning of the twentieth century. The attention of chemistry and molecular biology have long been turned to this strange but common substance, aspiring to achieve something productive and marketable. 
In fact, something marketable was achieved and the certification of the invention came through the patent law ${ }^{4}$. Furthermore, this product involved what we call nowadays Traditional Knowledge, and it was the curare complex: a traditional substance related to Amerindians' praxis in the Amazon region known as the province of poisons (CRULS, 1995).

A category that is certainly imprecise, Traditional Knowledge is a concept that plays an important role in the international scenario, as it makes feasible counterhegemonic actions. It also put some lights at what Vandana Shiva called the "plunder of knowledge" (SHIVA, 2001), a certain practice that has been perpetrated by the Western world and its distinguished capacity to asserts itself as the center of production of validly knowledge, which I would like to designate as conservative science ${ }^{5}$.

Even more remarkable is the role played by the concept at the WIPO Development Agenda, because it represents "propositions or demands from developing countries to make the international intellectual property system work in their interests rather than to coalitions involving the interests of the transnational industry based in developed countries" (POLIDO, 2013, p. 491, translated by the author). Thus, the idea of Traditional Knowledge imposes an epistemological limit at the unrestrained advances of Western reasoning and encourage a certain flourishment of other forms of knowledge - formerly left at the veil of invisibility or constant qualified as a non-trustworthy tradition.

I called an epistemological limit because our traditional way of thinking and conceptualizing the world is not the only one possible, as I tried to infer with the epigraph. But if that is not something easy to imagine, I want to express that limit by using an explanation we find in Eduardo Viveiros de Castro anthropology, that is: to take the native seriously. That means to take the Traditional Knowledge articulated at everyday practices as a form of concept. In other words, that implicates the impossibility to reduce it to empirical analysis or anything that disregard its abstraction as a representation, full of meaning on the context that it is used. With the power of metaphor, Eduardo Viveiros de Castro says:

To be clear: I am not suggesting that Amerindians "cognize" differently to us, or that their "mental" categories are different to those of any other human being. Certainly, it is not a matter of imagining them as instantiating some peculiar form of neurophysiology that processes difference in a different way. For my own part, I am

\footnotetext{
${ }^{4}$ The product developed was named Intocostrim and patented by Bristol-Myers Squibb Lab.

${ }^{5}$ Boaventura de Sousa Santos has a great amount of work on this issue. See, as an example, SOUSA SANTOS, Boaventura. Um discurso sobre as ciências. 3 ed. São Paulo: Editora Cortez, 2003.
} 
Notes on the concept of Traditional Knowledge and its relation to Intellectual Property Rights E-ISSN: 2316-8080

inclined to think that Ameridians ${ }^{6}$ think exactly "like us". But I also think that what they think, that is, the concepts that they deploy, the "descriptions" that they produce, are very different to our own - and thus that the world described by these concepts is very different to our own (VIVEIROS DE CASTRO, 2013, p. 484-485).

Within this framework we can risk setting some characteristic that will constitute a normative approach of the concept of Traditional Knowledge. I understand those as forms of knowledge associated with traditional people, ranging from indigenous people to forms of cultural expression that are linked to a certain ancestry to invent and reinvent itself in direct relation to concrete realities of daily lives. Whether through extractive cultivation as the coconut-babassu-breakers in Maranhão (PORRO; MENASCHE; NETO, 2014), or through the production of remedies and ways of healing of Rio Negro's riverside populations (SANTOS, 2000), the Traditional Knowledge are forms of knowledge that are constituted differently than the western analytic way of formation, transmission and modification of knowledge.

The formulation and transmission techniques of those kinds of knowledge are not based on the ways of reading and writing of the Western tradition, but other activities are import, such as swimming, walking, hunting, producing a balaio etc. To express this idea, I borrow the words of Ailton Krenak: "I believe that when a culture chooses these activities as things that have value in themselves it is excluding from the 'citizenship' thousands of people for whom the activity of writing and reading has nothing to do with it" (COHN, 2015, p. 86, translated by the author).

There is a relationship with the earth and environment, without which their own ways of life would not be possible. Manuela Carneiro da Cunha writes that "what all these people have in common is a good environmental record based on low impact techniques and a stake in retaining or regaining control of the territory they exploit" (CARNEIRO DA CUNHA; ALMEIDA, 1999, p. 317), making clear the cosmological distinction between Traditional Knowledge and Western practices.

This does not mean that Traditional Knowledge is stagnant in time, not even a form of knowledge that do not interact with the market, because if that were truth the only remain area of study would be Archeology. As an example, we could cite the economy of the remaining

\footnotetext{
${ }^{6}$ Viveiros de Castro is an americanist ethnologist and worked at the Amazon region. He does not analysis the concept of Traditional Knowledge itself, but I think that his ideas with Ameridians help us to represent what I am calling the epistemological limit at intellectual property rights.
} 
Tupinambá people of the south of $\mathrm{Bahia}^{7}$ that created its own association to administrate the production in order to have substantial ground to fight for land rights. The resignification of common concepts is an ongoing process in cultural theories ${ }^{8}$, whose best account can be seen the following definition: "culture is not a system of beliefs but rather - since it has to be something - a set of potential structures of experience capable of supporting traditionally varied content and absorbing new ones" (VIVEIROS DE CASTRO, 2002, p. 209, translated by the author).

Returning to the concept per se, we can never lose sight that this idea is invented by us and used in our legal and social constructions. Perhaps - or most certainly - it does not make any sense if we reverse the perspectives. If we could assume the perspective of the other what would be left is, I suspect, a denial in the same sense as the following:

\begin{abstract}
When the writer Daniel Munduruku was asked whether he "as an Indian," etc., he cut in the act: "I am not an Indian; I am Munduruku ". But being Munduruku means knowing that there are Kayabi, Kayapó, Matis, Guarani, Tupinambá, and that these are not Munduruku, but neither are White. Those who invented the "Indians" as a generic category were the great specialists in general, the Whites, or on the other, the white, colonial, imperial, republican State (VIVEIROS DE CASTRO, 2017, p. 189, translated by the author).
\end{abstract}

Those who invented the concept of Traditional Knowledge, to establish a parallel with Geertz, "were connoisseurs of cases in point" (GERTZ, 1983), or the jurists themselves. But that does not mean the concept has no importance to traditional people, once they are able to rearrange and redefine some Westen perspectives in their own favor ${ }^{9}$. To go one step further, I believe it to be a relational concept that involve (or is capable of) something very similar to that relation between "the observer and the observed" that Roy Wagner (1981) has presented to us, that is: when we are inventing the concept we also invent our own perspective, which can create a certain level of communication and interaction to the Traditional Knowledge holders without othering them. Hence the importance of applying this concept within Intellectual Property as the WIPO Development Agenda does, especially when we witness an Intergovernmental

\footnotetext{
${ }^{7}$ This information was passed through an oral communication by Cacique Babau - an indigenous leadership of Tupinambá - at the meetings of Traditional Knowledge held by Federal University of Minas Gerais, sept. 2018. To an ethnographic work related to Tupinambá of Souh of Bahia see: VIEGAS, Susana de Matos. Terra Calada: os Tupinambá na Mata Atlântica do Sul da Bahia. Rio de Janeiro: 7 Letras, 2008, 344 p.

${ }^{8}$ See WAGNER, Roy. The invention of culture. Chicago: The university of Chicago Press, 1981. See also CARNEIRO DA CUNHA, Manuela. Cultura com aspas: e outros ensaios. São Paulo: Cosac Naify, 2009.

${ }^{9}$ An interesting discussion that can illustrate this point can be seen in CONKLIN, Beth a. Body Paint, Feathers, and VCRs: aesthetics and authenticity in Amazonian activism. American Ethnologist, n. 4, v. 24, nov. 1997, p. 711-737. Disponível em: https://www.jstor.org/stable/646806?seq=1\#page_scan tab_contents. Accessed on: 12 dez. 2018.
} 
Notes on the concept of Traditional Knowledge and its relation to Intellectual Property Rights E-ISSN: $2316-8080$

Committee on Intellectual Property and Genetic Resources, Traditional Knowledge and Folklore (IGC) that discuss the protection of Traditional Knowledge, allowing other potentialities on the horizon of Intellectual Property Rights. The Committee aims to achieve a treaty of international law that ensures effective protection of Traditional Knowledge, traditional cultural expressions and genetic resources ${ }^{1011}$.

As a background there is an attempt to establish a long-standing dialogue in the academic field (GOMES, 2010; LACOMINI, 2007): the need to equalize the cornerstone of intellectual property (TRIPS Agreement) and the Convention on Biological Diversity (CBD). On one side, "the protection and enforcement of intellectual property rights should contribute to the promotion of technological innovation and to the transfer and dissemination of technology, to the mutual advantage of producers and users of technological knowledge [...]" (Article 7 of TRIPS agreement). On the other side, there is the concern about "[...] the conservation of biological diversity, the sustainable use of its components and the fair and equitable sharing of the benefits arising out of the utilization of genetic resources [...]" (Article 1 of CBD).

Considering that discussion, the conservation of biological diversity is the conservation of traditional forms of cultural expression and their knowledge, given the interrelation expressed above. Nevertheless, art. $8 \mathrm{~J}$ of the CBD further emphasizes that the parties should promote the conservation in situ:

Each Contracting Party shall, as far as possible and as appropriate:

(j) Subject to its national legislation, respect, preserve and maintain knowledge, innovations and practices of indigenous and local communities embodying traditional lifestyles relevant for the conservation and sustainable use of biological diversity and promote their wider application with the approval and involvement of the holders of such knowledge, innovations and practices and encourage the equitable sharing of the benefits arising from the utilization of such knowledge, innovations and practices (BRASIL, 1998)

Except for the due proportion, what the meetings of IGC committee seeks to achieve is this integration, as can be seen in the Draft Legislation 35/04 ${ }^{12}$. In any case, in reaching this

\footnotetext{
${ }^{10}$ See Intergovernmental Committee (IGC) at WIPO. Available at: http://www.wipo.int/tk/en/igc/.

${ }^{11}$ Negotiations are advanced already existing a Introduction to Consolidated Document Relating to Intellectual Property and Genetic Resources made by Professor Margo A. Bagley, and brings a draft project. Available at:

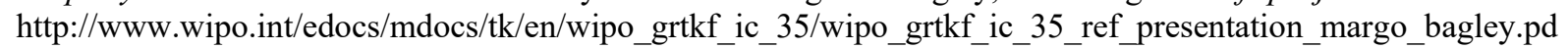
f.

12 See Introduction to Consolidated Document Relating to Intellectual Property and Genetic Resources made by Professor Margo A. Bagley, and brings a draft project. Available at:
} 
objective we will be witnessing nothing more than the implementation of the Development Agenda. However, some points must be emphasized in order to make more evident the latent meanings of this interrelationship.

What I see clearly is that there is no impediment to innovation, the contrary: the preservation of Traditional Knowledge is an impulse, as it always has been, and we should start seeing it also as innovation. Let us not be fooled by the dreadful logic that Western science operates, because as Comforto (2004, p. 360) alerts almost half of all plant-based medicinal drugs from all over the world have their origins in countries of the South, specifically countries rich in biodiversity such as Brazil, India, Ecuador and so on. In addition, 74\% (CONFORTO, 2004, p. 360) of these drugs were discovered through simple research on native popular claims. In other words, this means that traditional plant knowledge associated with the biodiversity of megadiverse countries is the basis for the production of large and important drugs throughout the West.

Likewise, it seems to me that a certain normativity of the concept of traditional can be drawn from the framework set above. This is of highest importance, as has already been pointed out, but the conflicts highlighted in the introduction appears. Associated with the logic of development is that of innovation, and, given the importance of traditional forms, protecting it is to provide space to other practices to emerge as also innovations and, thus, enlarging legal and morally our own approach of what can be called innovation. Then, beyond the epistemological limit, we also have a normative one capable of facing the unhindered bioprospecting perpetrated nowadays, which sometimes sounds more like a new form of biopiracy. In that point, Manuel Soria-Lopez and Israel Fuentes-Paramo explains:

\begin{abstract}
'Biopiracy' is an emergent term used to name illegal or improper appropriation of Traditional Knowledge and biological materials. Both of these are typical and endemic to specific countries and regions of rural or indigenous cultures mostly located in developing countries of the South. [...] happens when firms, universities, R\&D organizations or entrepreneurs mainly from developed countries of the North register patents that exploit Traditional Knowledge and biodiversity industrially and commercially. Biopiracy is done without the consent, permission and/or benefit sharing agreements of the carriers of Traditional Knowledge and guardians of biodiversity (SORIA-LOPEZ, 2016, p. 167).
\end{abstract}

Many of these practices are placed by the logic of Intellectual Property itself, and it is, among other reasons, against these predatory practices that I seek to interpretively establish a

http://www.wipo.int/edocs/mdocs/tk/en/wipo_grtkf_ic_35/wipo_grtkf_ic_35_ref_presentation_margo_bagley.pd f. 
Notes on the concept of Traditional Knowledge and its relation to Intellectual Property Rights E-ISSN: $2316-8080$

normative limit of the concept of Traditional Knowledge. Adopting some scientific evidence confirmed elsewhere (?), the current legal benchmark in intellectual property did not prevent biopiracy practices from being executed, which also contributes to the hypothesis of Shiraishi Neto and Fernando Dantas (2008): the procedures to access and the current regulation of Traditional Knowledge lead to a commodification (Commoditization) of traditional practices and knowledge.

In my view, this is precisely due to the non-confirmation of the epistemological and normative limits in the political praxis of WIPO, softening them all the time through actors of this predatory scenario, as one can always observe in the practices United States Patent Office (USPTO).

What intrigues us is that this practice is a zero-sum. In perpetrating a biopiracy, a plundering of the knowledge-base of these "innovations" is refined and, in the symbolic sense, we can say that the traditional forms are totally invisible. Making them invisible opens the door for other destructive practices, such as the advance of mining on indigenous protected areas ${ }^{13}$ and the displacement of riverside for dam construction ${ }^{14}$, even if this may be a mere militant intuition.

There is no need much effort to see that in the end we are witnessing an exhaustion of the very sources of our modern "innovations", at least in the pharmaceutical and therapeutic fields. Hence to think the opposite terms highlighted is, from a perspective of hermeneutic anthropology, to rethink them. In any case, to rethink that these oppositions show another exhaustion, the one of the old legal categories that are unable to define new perspectives that arise from the boundaries imposed by concept of Traditional Knowledge.

Nonetheless, if the view presented until now could be qualified as positive, in recent years there has been a great loss of certain rights achieved through social struggles by traditional people. Brazil seems to have left aside the interests that culminated in the Development Agenda,

\footnotetext{
${ }^{13}$ I refer to the emphasis given by the Special Rapporteur on the rights of indigenous peoples on a special mission to Brazil. Specifically, to item $\mathrm{C}$ of the report. Available at: http://www.mpf.mp.br/atuacaotematica/ccr6/eventos/2017/relatorio-da-onu-sobre-direitos-dos-povosindigenas/RELATORIOONU2016 pt.pdf. Accessed on: 16 aug. 2018.

${ }^{14}$ For exemple : ROQUETTI, Daniel Rondinelli et al. Deslocamento Populacional Forçado por Grandes Barragens e Resiliência Socioecológica: O Caso da Usina Hidrelétrica de Barra Grande No Sul do Brasil. Ambiente e Sociedade,v. 20, n. 3, São Paulo, 2017.
} 
especially with regard to the protection of traditional practices and the demand expressed in recommendation 18th.

We are experiencing a stagnation of land demarcation, ethnocentric theses such as the "temporal landmark"15, genocide of isolated indigenous people ${ }^{16}$, the advancement of mining ${ }^{17}$, Brazil's non-ratification of the Nagoya Protocol ${ }^{18}$ and the advance of some legal benchmarks such as the Biodiversity Law. The latter, very delicate to the traditional people and communities, entered the national public sphere after 14 years of Provisional Measure ${ }^{19}$ 2.186/01. As a result of collective aversions to previous dispositions, the Federal Law 13.123/15 counted on with an special actor in its drafting that was found worthy of receiving a special greeting by the Brazilian former president: "I wanted, when opening this speech, to direct a special compliment to a person who fought hard for the approval of this Law, by the sending of that Law. I am referring to the president of Febrafarma [FarmaBrazil Group], [Reginaldo] Acuri". ${ }^{20}$

Given that the sense of justice is very clear at the norm, it is still valid to point out that some scientific investigations are trying to review the legislative process to verify the hypotheses that the true social agenda of traditional people was not adopted (AUTOR, DATA). Important issues set in the National Congress by the traditional peoples' agenda were not institutionalized $^{21}$. It is enough to observe some very interesting legal categories that were

\footnotetext{
${ }^{15}$ A remarkable analysis of the regression represented by the temporal landmark is made by SOUZA FILHO, Carlos Frederico Marés. Marco Temporal e direitos coletivos. In: CARNEIRO DA CUNHA, Manuela, BARBOSA, Samuel (org.). Direitos dos povos indígenas em disputa. São Paulo: Editora Unesp, 2018.

${ }^{16}$ See the report of the Socio-environmental Institute. Mehalem, Leandro; Almeida, Robeto. Massacre de índios isolados expõe o estrangulamento da Funai. ISA, 14 set. 2017. Available athttps://www.socioambiental.org/ptbr/noticias-socioambientais/massacre-de-indios-isolados-expoe-o-estrangulamento-da-funai.

${ }^{17}$ I refer to the project know as "Belo Sun", in an indigenous protected area of Xingu river. See, for exemple: BRUM, Eliane. O que o velho Araweté pensa dos brancos enquanto seu mundo é destruído? El país, feb. 6, 2017. Available at: https://brasil.elpais.com/brasil/2017/02/06/opinion/1486385972_496318.html. Accessed on: 16 set. 2018.

${ }^{18}$ See the debate at the Brasilian Lower House. Available at: http://www.camara.gov.br/proposicoesWeb/fichadetramitacao?idProposicao=547397. Accessed on: 16 aug. 2018. ${ }_{19}$ At Brazil, like Spain and other countries, the President has the power, given by the Constitution, to establish some norms that latter must be approved by the Congress.

${ }^{20}$ Translated by the author from: ROUSEFF, Dilma. Discurso da presidenta. Brasília-DF, 20 mai. 2015. Available at: $\quad$ http://www.biblioteca.presidencia.gov.br/presidencia/ex-presidentes/dilma-rousseff/discursos/discursos-dapresidenta/discurso-da-presidenta-da-republica-dilma-rousseff-durante-cerimonia-de-sancao-do-novo-marcolegal-da-biodiversidade-que-regulamenta-o-acesso-ao-patrimonio-genetico-e-ao-conhecimento-tradicionalassociado-brasilia-df. Access on: 14 aug. 2018.

${ }^{21}$ Letters and requests for veto have been drafted and published in the period of debate by numerous communities and traditional peoples. See, for exemplo: Organizações e Movimentos Sociais repudiam projeto de lei que destrói biodiversidade nacional. Available at: https://terradedireitos.org.br/noticias/noticias/organizacoes-emovimentos-sociais-repudiam-projeto-de-lei-que-destroi-biodiversidade-nacional/16975. Access on: 20 jun. 2018. Furthermore: Moção de repúdio dos povos indígenas, povos e comunidades tradicionais e agricultores familiares aos setores empresariais envolvidos na elaboração e tramitação do projeto de lei que vende e destrói
} 
Notes on the concept of Traditional Knowledge and its relation to Intellectual Property Rights E-ISSN: 2316-8080

created by the Law, such as Traditional Knowledge of unidentified origin ${ }^{22}$ - whose use does not require prior consent. Another point that draws attention is the quantum of participation left to communities and traditional people in the Genetic Heritage Management Council (CGen), which is the "collegiate body of deliberative, normative, advisory and recusal character, responsible for coordinating the elaboration and the implementation of policies for the management of access to genetic heritage and associated Traditional Knowledge and benefit sharing" (BRASIL, 1994, translated by the author). The higher amount of representation that traditional people could achieve is $13,3 \%$ of the body of CGen.

Therefore, a paradox emerges but with different regard from those at the binging: there is a distancing approach presented at the Development Agenda and the laws promulgated at Brazil.

Certain that the history of the traditional people is marked by struggles and resistance, we should be concerned about an institutional context in which the legal forms reinforces the boundaries of what is considered valid knowledge without enlarging its own approach. In this position, I would like to borrow a passage of Roy Wagner and adjust it to our context: "[A Law] which never leaves the boundaries of its own conventions, which disdains to invest its imagination in a world of experience, must always remain more an ideology than a science" (WAGNER, 1981, p. 13).

Nevertheless, considering this scenario, it is important to enter the issues of international patent law and discuss the questions formulated initially.

\section{The limits of Patent Law}

a biodiversidade nacional. Available at: https://mobilizacaonacionalindigena.wordpress.com/2015/03/20/mocaode-repudio-dos-povos-indigenas-povos-e-comunidades-tradicionais-e-agricultores-familiares-aos-setores-

empresariais-envolvidos-na-elaboracao-e-tramitacao-do-projeto-de-lei-que-vende-e-destroi-a/. Access on: 20 jun. 2018.

${ }^{22}$ the referring articles are:

Art. $2^{\circ}[\ldots]$

III - conhecimento tradicional associado de origem não identificável - conhecimento tradicional associado em que não há a possibilidade de vincular a sua origem a, pelo menos, uma população indígena, comunidade tradicional ou agricultor tradicional;

Art. $9^{\circ}[\ldots]$

$\S 2^{\circ} \mathrm{O}$ acesso a conhecimento tradicional associado de origem não identificável independe de consentimento prévio informado. In BRASIL. Congresso Nacional. Decreto n. 1.355, de 30 de dezembro de 1994. Diário Oficial [da] República Federativa do Brasil, Poder Executivo, Brasília, DF. Available 
If conjecturing an answer to the problems raised above is quite complex - specially the dismantling of Traditional Knowledge after year of struggle to achieve its normativity and impose the epistemological limit as we called it -, I believe it is only possible if we consider the perspective of the traditional peoples, which will enable the resumption of intercultural dialogue. However, still remains the challenge to understanding the patent right in this properly "frontiered" relationship. If the national and international debate focused heavily on the concept of Traditional Knowledge and the possibilities for innovation, I would like to dedicate this section to discussion of the semantics of patents and how Traditional Knowledge challenges some old categories.

As varied as the national legislations can be, the central prerequisites to the conception of patent monopoly remains the same and are placed by the fulfilment of three characteristics presented in article 27 of TRIPS agreement. Those characteristics states that the invention shall be new, involve an inventive step and are capable of industrial application. In order to have an invention that may be protected by patent rights, it is necessary to fill all the requirements cumulatively, which goes through the expert review involved in the analysis of the different local offices.

It is necessary to note that the configuration of patent system, including the fulfillment of the prerequisites, take as their founding core the technical element. In other words, the expert review of novelty, industrial applicability and inventive step rests on the technical verification of the invention, specifically described in the descriptive report.

The novelty prerequisite is one that evaluates if the technical solution described does not exist in the public domain, that is: the novelty is not available in the state of art. In contrast, the inventive step observes the invention under the lens of non-obviousness, that is: "which is not evident or obvious from the state of art, when ascertained by an expert"(CHAMES, 2005, p. 4 , translated by the author). Finally, industrial application has a pragmatic character in relation to the invention, requiring, in other words, a utility of the invention in an industrial chain of production; a certain "susceptibility of use or industrial application" (CARVALHO, 2009 , p. 98 , translated by the author).

This points to a difficult task, since the invention that presents these prerequisites must be granted, revealing that grating a patent means only a certification of technical elements, not a substantial evaluation through the real meanings of the knowledge presented in the patent application. How then can one say that a patent which has as its background Traditional 
Notes on the concept of Traditional Knowledge and its relation to Intellectual Property Rights E-ISSN: $2316-8080$

Knowledge, but fulfills the above prerequisites, should not be granted? what are the limits of an invention? What does the technical really means as the gravitational core of the patent?

These problems were, and still are, the crucial points of the conflict between the authors $^{23}$ who defend the impossibility of patenting the Traditional Knowledge (SHIRAISHI NETO; DANTAS, 2008) and the authors who defend its possibility (DOWNES , 2000). I think it is a conflict or a dispute over the technical elements, precisely because it is what guarantees the balanced fulfillment of the prerequisites of an invention. No empirical work really discusses this point, which does not mean that the Law is not subject to the modulations of the technical or the advances on the technical world. As Supiot warns us, it is a question of "understanding that law and technology participate in the same culture and advance at the same pace" (SUPIOT, 2007, p.140, translated by the author).

In my view, the technical element of a patent has no value. The value of it derives from the meanings we offer to it, therefore: it is not an immanent characteristic, but an attribute that the field of Law places. Clearly, it is the development of techniques that offer a transformation of Law imbued in a constant relationship of conceptual transformation, for example: one did not have to think legally or legislate about conditions related to artificial intelligence before its existence.

I think it is not enough a mere verification ${ }^{24}$ of prerequisites, because it is incapable of understanding the conceptual extensions that may be involved in the invention. "The technical object is distinguished from the natural object by the fact that its meaning comes from the man who models and uses it" (SUPIOT, 2007, p. 140, translated by the author). This means that we must bear in mind our conceptual limitations in characterizing a patent that involves Traditional Knowledge, since it is not only our sense expressed but also perspectives that cannot be sharped as a simply natural object. To make things clearer, it is not possible, as did Loren Miller, to apply for a patent invention on a particular strain of Ayahuasca, arguing that it was possible to apply since there were no records in the public domain on such invention (FECTEAU, 2001).

\footnotetext{
${ }^{23}$ Interesting is the debate hold by the EASA (European Association of social Anthropologists) over culture and economy, in 1998. See STRATHERN, Marilyn et. al. Exploitable Knowledge belongs to the creator of it: a debate. Social Anthropology. v. 6, n. 1, p. 109-126, fev. 1998. Available at: <hhttps://onlinelibrary.wiley.com/doi/abs/10.1111/j.1469-8676.1998.tb00385.x >. Accessed on: 25 out. 2018.
} 
I must specify my approach. Unlike an invention of new technologies, the invention of Traditional Knowledge is not meaningless in itself. This is exemplified if we take the above case and understand that "for hundreds of years, shamans have used ayahuasca to treat sicknesses, contact spirits, and foresee the future" (FECTEAU, 2001, p. 69). It is for this symbolic dimension that I would like to draw attention, for whatever the uses we may take the proposition and application already structured in traditional practices could not simply left aside. Otherwise we will be perpetuating the abyssal lines ${ }^{25}$ in Intellectual Property. That is: a perpetuation of a system in which the only view of the world is the ontological reduction presented by the West, putting the rest under an invisible vail.

In this context, I oppose myself to what Nuno Pires affirms: "Patents are neutral instruments and serve both industrial policy objectives and ownership of the tangible goods that encapsulated inventions" (CARVALHO, 2009, p. 77, translated by the author). I do not believe it to be neutral, for behind it lies the classical policy of distinction between the subject and the object, which may not be a question of ontological order as it is proposed within the western tradition, but it is a cosmological one. It is to understand beyond these concepts that contemporary philosophy cannot overcome and comprehend that within the traditional there is a multiplicity of perspectives intrinsic to the real that breaks with the cosmic solipsism, fiercely committed to encapsulate the potentialities in normative contours of easy handling.

Reducing Traditional Knowledge to the descriptive field of a report can corroborate to parameters that make no sense if we reverse the points of view. What we are really doing when grating a patent related to Traditional Knowledge is objectification, which means the certification of what is valid and what is not through the technical verification of novelty, inventive step and industrial applicability. The work of Noemi Miyasaka Porro et al. related to coconut-babassu-breakers in the state of Maranhão shows quite clear what I intended to express:

However, the dissociation between Traditional Knowledge and the groups' ways of doing, creating and living violates the collective rights of coconut breakers, since for them there is no separation between subject and object, in the case of nature, represented by the palm mother. On the other hand, environmental policymakers, conditioned by international conventions and protocols, have been thinking and constructing nature away from the subject and as an appropriate resource through the market (PORRO; MENASCHE; NETO, 2014, p. 279, translated by the author).

\footnotetext{
${ }^{25}$ The theorical perspective is created by SOUSA SANTOS, Boaventura. Para além do pensamento abissal: das linhas globais a uma ecologia dos saberes. Novos Estudos, n. 79, nov. 2007.
} 
Notes on the concept of Traditional Knowledge and its relation to Intellectual Property Rights E-ISSN: $2316-8080$

Therefore, I believe that there is no justification for applying a patent on Traditional Knowledge, precisely because they are knowledge of another order, pointing more to the need to rethink the essential points that characterize conservative science that I referred to.

On the other hand, the perspective presented has nothing to do with the impediments to the development of scientific field ${ }^{26}$. The proposal here is different, as it attacks directly the outlines of property - shown by a cosmological opposition - and seeks recognition of traditional practices, not only in the legal fields but essentially in a moral range. The question that normally rises in this moment is: what can we do? I do not have an answer to that question and I do not believe that we should have, because that would be the reproduction of only one saying about how the others should be treated into legal categories. Meanwhile we witness a deliberate extension of patent rights, as well as intellectual property as a whole, into previously unseen fields, what constitute part of the juridicization: referring to the extension of law and its legal processes to a growing number of economic and social life (VILLAS BÔAS FILHO, 2015).

After all, before even thinking about compensation and accountability regimes - which to a certain extent is represented by the influential ABS regime in the Convention on Biological Diversity, the Nagoya Protocol and the Law number 13.123/15 - one have to wage a debate on the frontiers of our westernized knowledge and how we are unable to comprehend what transcends our everyday legalism, and much more is needed than merely verification of the language presented by the questions of inventive step, industrial applicability and novelty.

\section{Conclusion}

Returning to the debate on intellectual property and patent law and their relationship to Traditional Knowledge, the conclusion possible is that traditional patent law promotes a legitimating of just one sort of "science", and that is the one in advantage with the technical element present in legal categories. In this way, the sense of protection through a patent does not interfere in the plunder of knowledge. To be sure, if there is a dismantling of the concept of traditional through preexisting legal categories, what would rest is an empty concept without any capacity to change the ongoing process of biopiracy. Reducing traditional practice to industrial applicability, inventive step, and novelty is too easy - and politically iniquitous.

\footnotetext{
${ }^{26}$ Not to mention that there is no link between the patent institute and the scientific advance, as the works of Petra Moser reveal. See MOSER, Petra. How Do Patent Laws Influence Innovation? Evidence from Nineteenth-Century World's Fairs. The American Economic Review, v. 95, n. 4, 2005, p. 1214-1236.
} 
Thus, to strengthen the concept is to promote recognition in the legal sphere of social struggles perpetrated by traditional peoples and communities. The institutionalization of the concept was the institutionalization of certain recognition, allowing the establishment of epistemological and normative boundaries to the predatory advances on Traditional Knowledge. In extent, this contributes to the scientific advance, since it is extrapolated to zerosum. But adopting simply technical verification in patents related to Traditional knowledge is the same that telling us that all the WIPO Development Agenda effort does not have any impact in the subject matter.

As we tried to demonstrate, there are immanent contradictions in patent law that would not mean anything if they could reverse the perspective, that is, the perspective of traditional peoples and communities. We should discuss and rethink our model and dare to ask ourselves a little more, that is, what would become of us classifiers if we are one day the classified? To end with the conceptual paradigm that sustains us: "We need, in the end, something rather more than local knowledge. We need a way of turning its varieties into commentaries one upon another, the one lighting what the other darkens" (GEERTZ, 1983, p. 233).

\section{References}

BRASIL. Congresso Nacional. Lei n. 9.279, de 14 de maio de 1996. Regula direitos e obrigações relativos à propriedade industrial. Diário Oficial [da] República Federativa do Brasil, Poder Executivo, Brasilia, Available at: $<$ http://www.planalto.gov.br/ccivil_03/leis/19279.htm>. Accessed on: 15 jun. 2018.

. Congresso Nacional. Decreto n. 1.355, de 30 de dezembro de 1994. Diário Oficial [da] República Federativa do Brasil, Poder Executivo, Brasília, DF. Available at: $<$ http://www.planalto.gov.br/ccivil_03/decreto/antigos/d1355.htm $>$. Accessed on: 15 jun. de 2018.

. Congresso Nacional. Decreto n. 2.519, de 16 de março de 1998. Diário Oficial [da] $\overline{R e p u ́ b l i c a}$ Federativa do Brasil, Poder Executivo, Brasília, DF. Available at: $<$ http://www.planalto.gov.br/ccivil_03/decreto/d2519.htm $>$. Accessed on: 15 de jun. 2018.

CARNEIRO CUNHA, Manuela. Deve o conhecimento ser livre? A invenção da cultura e os direitos de propriedade intelectual. Revista Sexta-Feira, n. 3, p. 93-98, 1998.

; ALMEIDA, Mauro W. B. Indigenous People, Traditional People, and Conservation in the Amazon. Daedalus, v. 129, n. 2, 2000, p. 315-338.

. (2009). Cultura com aspas: e outros ensaios. São Paulo: Cosac Naify. 
Notes on the concept of Traditional Knowledge and its relation to Intellectual Property Rights E-ISSN: 2316-8080

CARVALHO, Nuno Pires de. O futuro do sistema de patentes linhas de tensão e possíveis (senão provisórias) soluções. Rio de Janeiro: Editora Lumen Juris, 2009.

CHAMAS, C. Proteção Intelectual de Invenções Biotecnológicas. Cadernos de Estudos Avançados, Rio de Janeiro, v. 2, n.1, p. 47-57, 2005.

COHN, Sérgio (Org.). Encontros - Ailton Krenak. Rio de Janeiro: Azougue, 2015.

CONFORTO, David. Traditional and Modern-day Biopiracy:: Redefining the Biopiracy Debate. J. Envtl. Law And Litigation, Boston, v. 19, p.358-397, 2004.

FECTEAU, Leanne M.. The Ayahuasca Patent Revocation: Raising Questions About Current U.S. Patent Policy. Boston College Third World Law Journal, Boston, v. 21, n. 69, p.69-104, jan. 2001.

GEERTZ, Clifford. Local Knowledge: further essays in interpretive anthropology. $1^{\circ}$ ed. Basic Books, 1983, 244 p.

KWAKWA, Edward. Mainstreaming 'Development' in International Organizations. International Organization Law Review, v.6, n.1, 2009.

MITCHELL, Andrew D., VOON, Tania. TRIPS. In: Daniel Bethlehem et al. The Oxford Handbook of International Trade Law. Oxford: Oxford University Press, 2009, p.200-203

MOSER, Petra. How Do Patent Laws Influence Innovation? Evidence from NineteenthCentury World's Fairs. The American Economic Review, v. 95, n. 4, 2005, p. 1214-1236.

NETANEL, Neil Weinstock. The WIPO Development Agenda and Its Development Policy Context. In: . The development Agenda. Oxford Univ. Press, 2009.

POLIDO, Fabrício Bertini Pasquot. Direito Internacional da Propriedade Intelectual: fundamentos, princípios e desafios. Rio de Janeiro: Renovar, 2013.

PORRO, Noemi; MENASCHE, Renata; NETO, Joaquim S. Babaçu livre e queijo serrano: história de resistência à legalização da violação a conhecimentos tradicionais. Horizontes Antropológicos, Porto Alegre, vol.20, nº 41, Jan./June, 2014.

QIAN, Yi. Do National Patent Laws Stimulate Domestic Innovation in Global Patenting Environment: A Cross-Country Analysis of Pharmaceutical Patent Protection, 1978-2002. The Review of Economics and Statistics, v. 89, n. 3, 2007, p. 436-453.

SANTOS, Fernando. S. D. Tradições populares de uso de plantas medicinais na Amazônia. Hist. cienc. saude-Manguinhos, Rio de Janeiro, v.6, suppl.0, set. 2000.

SORIA-LOPEZ, Manuel; FUENTES-PÁRMO, Israel. The identification of biopiracy in patents. World Patent Information, v. 47, 2016, p. 167-74.

SOUSA SANTOS, Boaventura. Para além do pensamento abissal: das linhas globais a uma ecologia dos saberes. Novos Estudos, n. 79, nov. 2007. 
SHIRAISHI NETO, J. ; DANTAS, Fernando A. C. .A 'Commoditização' do Conhecimento Tradicional: notas sobre o processo de regulamentação jurídica. Revista Economia y Sociedad, Costa Rica, v.13, n.33/34, p. 119-131, 2008.

SHIVA, Vandana. Biopirataria: a pilhagem da natureza e do conhecimento. Petrópolis: Vozes. 2001.

SILVA, Tatianna Mello Pereira. Acordo TRIPS: One-size-fits-all? Revista de Direito Internacional, Brasília, v. 10, n. 1, p. 57-70, 20 jun. 2013.

STRATHERN, Marilyn et. al. Exploitable Knowledge belongs to the creator of it: a debate. Social Anthropology. v. 6, n. 1, p. 109-126, fev. 1998. Available at: http://onlinelibrary.wiley.com/doi/10.1111/j.1469-8676.1998.tb00385.x/abstract. Accessed on: 25 out. 2018

VIVEIROS DE CASTRO, Eduardo. A inconstância da alma selvagem. São Paulo: Cosac Naify, 2002.

. Metafísicas Canibais. São Paulo: Cosac Naify, 2015.

. The relative native. HAU: Journal of Ethnographic Theory, v. 3, 2013, p. 469-502.

. Os involuntários da Pátria. ARACE - Direitos Humanos em Revista, n. 5, (fev.) 2017.

WAGNER, Roy. The invention of culture. Chicago: The university of Chicago Press, 1981.

WIPO. Biopiracy: The plunder of nature and knowledge. Boston: South End Press, 1997. 15 jun. 2018.

. IP Statistics Data Center. Available at: https://www3.wipo.int/ipstats/. Accessed on:

. The 45 Adopted Recommendations under the WIPO Development Agenda. Available at: http://www.wipo.int/ip-development/en/agenda/recommendations. Accessed on: jun. 15, 2018. 